\title{
A Proposed Certification Process For Business Teachers In Jamaica
}

Gareth Phillips, (Email: gphillips@utech.edu.jm), University of Technology, Jamaica

\begin{abstract}
This paper proposes subject area certification requirement for business educators within the Jamaican education system and identifies the workplace skills and competencies for business educators and business students in Jamaica.
\end{abstract}

\section{INTRODUCTION}

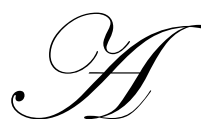

$t$ the heart of teacher certification is the issue of teacher quality within an education system. Every education system depends upon the quality of the teachers to realize its goals (Gold, 1996). A major challenge within the wider context of an education system is meeting the needs of students who must be able to function within the world of work. In order for students to make seamless transitions from the classroom to the workplace, it requires that teachers be equipped with the skills to adequately prepare students to fill these demands (Darling-Hammond, 1999; David, 2000).

The Ministry of Education, Youth and Culture, the government ministry with portfolio responsibility for education in Jamaica, data revealed that in 2003, only $20 \%$ of secondary level graduates held qualifications which would allow them to participate in gainful employment or enter post secondary programs. Additionally, the public education system employed 22, 363 teachers at all levels excluding tertiary and post secondary, and $83 \%$ were graduates from teacher training colleges. Of the total teaching force, only $20 \%$ were trained university graduates (2003). The table below represents the school types at which business education is offered as well as the qualifications of teachers within those schools.

Table 1

Teachers Employed In Public Sector Schools By Type Of School And Qualification (2003)

\begin{tabular}{|c|c|c|c|}
\hline School Type & $\begin{array}{c}\text { Trained University } \\
\text { Graduates }\end{array}$ & $\begin{array}{c}\text { Trained Teachers College } \\
\text { Graduates }\end{array}$ & $\begin{array}{c}\text { Pre-Trained University } \\
\text { Graduate }\end{array}$ \\
\hline Secondary High & 2,517 & 4,431 & 725 \\
\hline Technical High & 226 & 512 & 80 \\
\hline Vocational/Agricultural & 7 & 13 & 1 \\
\hline Total & 2,750 & 4,956 & 806 \\
\hline
\end{tabular}

Excerpt from Task Force on Educational Reform Jamaica Report, 2004. p.22

It is obvious from the table that the Jamaican education system needs more trained university graduates. Those graduates would complete studies at the bachelor degree level and have extensive exposure to the professional education courses making them better suited for teaching in the system. Holding a degree in education suggests that the graduate has sufficient knowledge of the subject matter and has demonstrated a high degree of mastery in the skills and techniques of teaching. Such a graduate would be ready and equipped to contribute to the transformation process necessary for the Jamaican education system.

The current thrust towards increasing the quality of teaching within the Jamaican education system, as proposed by the Task Force on Educational Reform Jamaica Report, 2004, provides the impetus for dialogue and decisions regarding the approach to standardize teacher education and by extension standardize the subject area 
practitioners' skills and expertise. Currently, no such system exists and what obtains is failing miserably. The following facts also point to the need for a revolution in the system: (1). a greater percentage of the teachers holding less than a degree in education, (2). a large number of teachers having no formal training in education, and (3). no structured regulation of teachers after initial registration upon entering the system. This results in continued underperformance by teachers, principals, and primarily, students. Among the many recommendations made by the Task Force is to "develop and implement a licensing and certification system for all teachers in Jamaica" (p.45).

While any subject specialization could be used as a model for the certification of teachers, Business Education has been chosen. This is due in part to the importance of Business Education to the survival of the economy within a country and so improving the output in business could potentially yield significant growth in a country's economy. According to the National Business Education Association (NBEA) Standards (1995), Business Education has a two-fold mission: to provide knowledge and skills for business and to provide knowledge about business. Those who participate in Business Education are expected to be productive citizens and informed consumers who are ready to enter the workplace and to function as economic beings within the wider society.

Business Education in Jamaica is part of the Technical Vocational Education Curriculum. Consequently, any meaningful discussions about Business Education must be within the ambits of that framework. Technical Vocational Education is constantly faced with the challenge of keeping pace with the rapidly changing workplace. Given the technological developments which give rise to new skills and making others redundant; the relocation and dislocation of workers as a result of migration and the need for training and retraining, teachers' skills and expertise must be as current as the trends and practices. This has implications for certification which ensures that teachers are ready to meet the demands of the profession (UNEVOC, 1997; Darling-Hammond, 1999).

\section{DEVELOPMENT OF BUSINESS EDUCATION}

Business education developed along the lines of economical and societal advancements, that is, as the society became more industrialized and later technological, the discipline expanded. With growth in commerce, it became necessary to have support from a highly educated workforce. This gave rise to a more structured and formalized vocational and technical training program. The demands increased, not just for large numbers of workers but for greater competencies among workers. Employment became extremely specialized and necessitated specialized training (Stitt-Gohdes, 2002).

The discipline started in the United States as part of a combination of courses offered to students in public schools. For example, students learned Casting Accounts which formed part of a business arithmetic subject. Students who intended on a career in business or commerce left school and entered apprenticeships. These apprenticeships served as the first type of school-to-work program. Given the Casting Accounts, it was a natural progression for bookkeeping to become the first business subject to be offered in schools (Hosler, 2000). Between the establishment of academic institutions and the passing of Bills by the United States Congress, the momentum for business education increased. Some of the outcomes included the development of colleges for business instruction, introduction of shorthand in public schools in 1862 as well as the invention of the typewriter in 1868. In 1862, the first comprehensive high school was established offering both college preparatory courses and vocational programs of study (2000).

Several new private business colleges were established in the early to mid 1800s to help meet the demands for a qualified workforce. These colleges were situated on the east coast of the colonies in the US where the seaports were located and commerce boomed. This reality was a major contributing factor to the development of business education as a field of study. The offering of Typewriting and later Keyboarding, prompted students to enroll in additional business subjects. The teaching staff was selected based on the extent of their business experience and not on their academic or pedagogical knowledge of the subject matter (Stitt-Gohdes, 2002). Later in the 1800s, Shorthand was introduced in the curriculum by John Robert Gregg from Great Britain and gained great popularity. Women were also given an opportunity to gain employment through free tuition offered by business colleges and the fact that gross numbers of the men were at war during the Civil War era. This practice continued post Civil War era and accounted for the large numbers of women joining the workforce (Hosler, 2000). 
Business education as a discipline while growing in the public school environment lacked the recognition at the state level necessary for sustained credibility. In an attempt to improve the importance of business education, several state supervisors were appointed as a result of the Vocational Education Act of 1963. Publishing companies also provided support by publishing textbooks and materials related to the discipline. The Consumer Education Study brought major changes in the high school curriculum and led to the formation of the Council for Consumer Information (CCI). Another significant development in business education came with the inventions of the electronic computer, the electronic numerical integrator and the calculator. All of those developments along with the establishment of standards continue to guide the profession and inform business education today.

\section{DEVELOPMENT OF TECHNICAL AND VOCATIONAL EDUCATION (BUSINESS EDUCATION) IN JAMAICA}

The earliest form of formal technical and vocational education in Jamaica began with the introduction of the 1954 Apprenticeship Act which allowed for learning under the guidance of a 'Master'. Later, the apprenticeship program gave way to more institutionalized training. In 1972, the Human Employment And Resource Training (HEART) Trust was established in response to the need for professional business support to under gird the Industrial Training Centers (ITC) which were established to provide manual training and a skilled labor force. These centers needed receptionists, typists, stenographers and bookkeepers to maintain business operations while they increased the numbers of highly skilled and trained industrial workers for the developing factories. With the increased demand for more office workers, the HEART Trust was unable to keep pace in training the required numbers of workers consequently, a big boost came when vocational education was introduced into the secondary school curriculum in 1974. Grades 10 and 11 students were given an opportunity to choose between being trained as an industrial worker or as an office worker. This move greatly impacted the number of trained office workers and thus enhanced what this paper refers to as business education. Business education offerings included Bookkeeping, Shorthand, Typing, Stenography, Office Practice and Principles of Business (Morris, 1996).

Vocational education being given a formal status within the secondary education curriculum necessitated the training of teachers in that area. The business teacher education program began as a pilot project in 1965 at the Shortwood Teachers' College and the College of Arts, Science and Technology (CAST). The program was geared towards producing qualified teachers to replace the recruits from abroad who came in the initial stages of the program. The formal delivery of the three-year teacher training programs in business education began in 1971 at CAST and was funded by the Jamaica/Canadian International Development Agency (CIDA) project for the development and expansion of the program. The programs were offered under the auspices of the Joint Board of Teacher Education (JBTE), the committee responsible for awarding certificates and establishing and maintaining standards in teacher education (Joint Board of Teacher Education, 2003). There were variations in the delivery modality: the three-year full-time diploma program, an intensive one year full-time program and the summer modularized program. The oneyear and the summer programs were offered for the upgrading of teachers.

The demand for more business teachers in the secondary system led to the expansion of the business teacher education program to include other teacher training institutions: Bethlehem Moravian Teachers' College, Church Teachers' College and Moneague Teachers' College. Over time, CAST became the University of Technology, Jamaica and continued to offer business education programs but upgraded to the degree level. Many graduates with a business degree could also earn a diploma in education and teach business at the secondary level (Joint Board of Teacher Education, 2003).

\section{CERTIFICATION}

Certification is a process that verifies the achievement of pre-established standards set by a professional or regulatory body and assures the industry or the profession that the individual possesses the qualification necessary for employment within the given occupation or occupational specialty (Brown, 1999). It is necessary to make a distinction between certification and licensure. According to Bradley (1995), certification is a non-statutory requirement while licensure is a restrictive process which grants permission to practice a profession so long as the 
requirements have been met. For Shulman and Sykes (1986), certification is described as that which validates the teacher's skill while licensure is the permit to teach.

An education system ensures that a teacher possesses the minimum requirements through teacher certification. In America, each state establishes its own standards for certification (ERIC Digest 11, 1986) while in Canada, standards are established on a province-wide basis (Child, Ross and Jaciw, 2002). The teacher certification process ensures that prospective teachers meet the professional standards established by the state education agency. An important feature of teacher certification is the ratification of the quality of competence in subject area, educational methodology, teaching skills, and potential classroom management ability by the prospective teacher (Roth and Mastain, 1984). This certification process is a legal process and allows in some cases the movement of teachers from one state to another.

There are many differences in the types of certification available. In the education industry, certification maybe offered for different categories of teachers, that is, regular teachers, principals, administrators, vocational teachers and so on. Additionally, certification may be offered for subject areas and grade levels. Another area of difference is the duration of initial certification. Currently, it ranges from one year in some states to ten years in at least two states (Iowa and Kentucky). In order to meet certification requirement, candidates must be a university graduate with a specified number of credit hours in coursework. In some states, certification is automatic for graduates from approved teacher education programs (ERIC Digest 11, 1986). In others, teachers must be successful on a state certification examination in order to be certified.

In the US, more current debates revolve around the issue of alternative certification. The shortage of teachers has led to a crisis in the education system. In an attempt to meet the demand for more teachers, other professionals who desire to teach are provided with an alternative route to certification rather than the traditional four year teacher education program. In some cases, an emergency credential is issued until the teacher completes the requirement for full certification. This gives rise to additional concerns for efficiency and effectiveness with regards to students' achievement (Goldhaber and Anthony, 2005; Nakai and Turley, 2003; ERIC Digest 1, 1986).

After initial certification, the teacher must be concerned with renewal requirements. Again, it varies from one state to the next. A teacher may have to enroll in graduate level courses, advance coursework or participate in such programs as Beginning Teacher Induction Program in order to meet re-certification requirements. Having satisfied the requirements, re-certification would be granted for another specified period of time (ERIC Digest 11, 1986).

There is a thrust towards a national certification process in the United States. The proposal presented in the Carnegie Forum on Education and the Economy (as cited in ERIC Digest 11, 1986) outlines a national certification plan. It is believed that national control of certification will achieve standardization of the process and provide greater management of teacher quality. To bolster the proposal, it was recommended that a national certification board and national certification examination be established and strong support be found within the teaching profession to maintain the process. The expectations are that each state will produce acceptable teachers for national certification. Additionally, states should benefit from economies of scale, the product of assessment as well as the standardization of the essential bodies of knowledge needed in the professionalizing of teaching (Baron, 1988).

\section{SUBJECT AREA CERTIFICATION}

Certification should guarantee quality of product but this notion is being challenged by the reality of the American education system. Students' performance on national standardized tests suggests that general certification such as state certification may not secure quality teachers. From all indications, some teachers acquire state certification but still lack the competence in content area. In fact, several states' certification requires no subject area testing. This serves as an indictment on most states since students' performance, a key indicator of the quality of teaching, shows a trending down in the figures reported for national standardized tests. There is consensus among stakeholders in education on the relationship of subject area competence and student achievement (Baron, 1988). Suh (2002) contends that teachers, who hold a major in the subject areas taught, are more qualified than those with a 
general education degree and achieve better student performance. The US National Board of Professional Teaching Standards recommends that all certification testing include testing of subject matter (Child et al., 2002).

There is considerable concern for the format of the certification testing. The earlier form of teacher certification tests administered in Canada used multiple-choice questions. Some educators felt that multiple-choice questions were an over simplification of the real complexities of teaching (Porter, Young and Oddens, 2001). Consequently, certification tests have been modified to include varying formats and may utilize simulations of classroom experiences, observations of teachers, essays, interviews, and oral defenses The National Board considered multiple assessment modes in order to finalize the structure of the national certification test (Baron, 1988).

\section{THE PROPOSAL}

Currently in Jamaica, individuals who complete a teacher education program and accept employment as a teacher are automatically registered with the Ministry of Education, Youth and Culture. There is no formal system of certification beyond receiving a teacher training certificate, diploma or degree. Teachers are not mentored in a standard way or guided to the point of honing their own skills in teaching. Some schools however may have local programs geared at helping first year teachers get settled but on a limited scale. Given the range of challenges plaguing the Jamaican education system, among which is the issue of teacher quality, it is necessary to identify the standards to be achieved by teachers and to approve a set of teachers as having met these pre-established standards for the discipline. It is against this background and the knowledge of the impact of the quality of the teacher on student performance that this paper is proposing subject area certification for the business teachers in Jamaica to be administered and monitored by the Joint Board of Teacher Education.

It will be assumed that all entry level teachers eligible for certification would have a bachelor degree in Business Education. The teachers must have completed an approved teacher education program in order to be considered eligible. Each candidate will have to sit a certification examination which must incorporate content specific to business education and those skills and competencies identified as crucial for the Jamaican business educator. Additional areas to be included on test are pedagogical theory and practice, methodology, classroom behavior management and general teaching skills and techniques. Consistent with international trends, the Jamaican certification process should include a number of assessment modes in order to give greater opportunities for teachers to demonstrate their competencies.

Teachers should score at least $75 \%$ in each of the categories in order to pass the overall test. The upper $25 \%$ percentile (based upon the bell curve) represents mastery of majority of the skill sets tested. This is to ensure that the prospective teacher possesses a desirable degree of competence in each sub-category and can function effectively in the classroom on his or her own. The $75 \%$ pass rate is lower than statewide pass rate for Michigan in Business Education whose pass rate is $76 \%$ (Robins, 2003), however higher than the pass rate for Texas which is only $70 \%$ (Poelzer, Zeng, and Simonsson, 2000). The implication is that over time, the pass rate in Jamaica will have to increase in order to be on par with international standards.

With regards to subject area competence, business teachers should have more than mastery of content. It is equally necessary for those teachers to possess the critical skills and abilities required of graduates from the business education program by employers. Demonstration of competence in those skills and abilities would suggest teacher's readiness to impart to students those skills and abilities. In order to propose those areas to be included on the certification test, it was necessary to get indication from employers of the skills and abilities critical for success in entry level employment.

According to Raymond, McNabb \& Matthaei (1993), there were eleven (11) employability skills and competencies required by employers in the United States and are identified in table 2. These skills and competencies were matched against employability competencies identified in the SCANS Report of 1992 and a final list was developed. The Delphi Technique was used to collect data from a panel of 20 experts consisting of three (3) business educators and four (4) other technical vocational educators who are functioning as employers, one (1) NGO manager, and twelve (12) business executives mainly from the financial sector. Given the nature of the data needed for this 
paper, the Delphi Technique was the most suited, providing experts' quick, accurate, and efficient forecast of current trends and patterns as well as for the future (Weaver, 1971).

Table 2

Business Graduates Skills And Competencies Required By Employers In The United States

Skills and Competencies

\begin{tabular}{|c|}
\hline Oral Skills \\
\hline Dependability \\
\hline Interpersonal Skills \\
\hline Written Skills \\
\hline Self-starter \\
\hline Motivation \\
\hline Enthusiasm \\
\hline Meet Deadlines \\
\hline Quantitative Skills \\
\hline Functional Skills \\
\hline Work Experience \\
\hline
\end{tabular}

A list of sixteen (16) skills and abilities were compiled for the first round of the Delphi Technique and the panel of experts identified the ten (10) most desirable skills and abilities (see table 3). The results were compiled for the second round and redistributed. In this round, it was a more difficult task for the panelists who had to decide on the order of importance of the selected skills and abilities.

Table 3

Ten Most Desirable Skills And Abilities Required Of Business Graduates In Jamaica

\begin{tabular}{|c|c|} 
Skills and Abilities \\
\hline Oral Skills & Problem Solving \\
\hline Dependability & Team Player \\
\hline Interpersonal Skills & Computing Skills \\
\hline Written Skills & Meet Deadlines \\
\hline Motivation & Self Management \\
\hline
\end{tabular}

Many of the skills identified by Raymond et al. (1993) for the US business place matched those skills required in the Jamaican workplace. There were four skills identified as unique for the Jamaican workplace, they are computing skills, team player, problem solving and self management. These skills, it could be argued are incorporated into the category called functional skills by Raymond et al. (1993). However, a major component of the functional skills is knowledge needed to perform the job which is not implied anyway in those four skill sets. Generally, the skills necessary for the Jamaican workplace are the skills necessary for other parts of the world. This suggests and underscores the importance of the internationalization of the Business Education curriculum. Consequently, the kind of preparation for business useful in countries like America may be useful in Jamaica. Additionally, graduates from Jamaican business education programs having certified business educators, should be able to function in America's or a comparable country's workplace.

Identifying the order of importance of the selected skills and abilities for the Jamaican workplace only serves as a guide to the designers of the certification examination in determining the emphasis to be placed on each of the sub-components within the content area to be included in the examination. 
Table 4

Employers' Ranking of Skills and Abilities for the Jamaican Workplace

\begin{tabular}{|c|c|c|}
\hline Skills and Abilities & Order of Importance & Percentages \\
\hline Oral Skills & $1 / 2$ & $30 \%$ \\
\hline Dependability & 3 & $40 \%$ \\
\hline Motivation & 4 & $40 \%$ \\
\hline Self Management & $1 / 5$ & $40 \%$ \\
\hline Interpersonal Skills & 5 & $30 \%$ \\
\hline Computing Skills & 6 & $30 \%$ \\
\hline Team Player & 6 & $30 \%$ \\
\hline Written Skills & $8 / 9$ & $30 \%$ \\
\hline Meeting Deadlines & $9 / 10$ & $30 \%$ \\
\hline Problem Solving Skills & - & - \\
\hline
\end{tabular}

* percentages have been round-up

There were only eight (8) of the panelists who completed the second round and one result could not be used. Consensus was rare and often times limited to no more than three (3) members agreeing on any skill or ability. From Table 4, it appears that Oral Skills were ranked the most important skill for the Jamaican workplace while Meeting Deadlines was the least important. The skills and abilities with the higher percentage were Dependability, Motivation and Self Management. There was no consensus among the panelists with regards to problem solving skills. However, as an individual item, its ranking ranged from one to ten (10) with greater occurrences between six (6) and ten (10). The implication for the certification examination would be that there should be several opportunities for demonstration of dependability, high levels of motivation and successful self management practices by the teacher candidates.

These are preliminary findings and further research is necessary to get a more complete feedback for improving the business education curriculum. However, this kind of feedback proves very useful for designing the business education certification examination.

\section{CONCLUSION}

The purpose of this paper was to propose a certification process that will improve the quality of teaching among business educators in Jamaica. This need became apparent after the Task Force on Educational Reform recommended in its Report, the development and implementation of certification for all teachers in Jamaica. A certification examination was proposed with strong emphasis on the subject matter competence which should include demonstration of oral skills, written skills, interpersonal skills, computing skills, problem solving skills, and the ability to be a team player and meet deadlines. There should be greater opportunities for teacher candidate to demonstrate dependability, motivation and self management techniques. The other examination components should be pedagogical theory and practice, methodology, classroom behavior management and general teaching skills and techniques.

The examination should utilize multiple modes of assessment: case studies, essays, multiple choice, observation, portfolios and interviews. An initial pass mark of $75 \%$ in each of the examination components was recommended to reflect achievement of a relatively high degree of competence on each component. For centralization of the management process, it was recommended that the Joint Board of Teacher Education be responsible for all aspects of management including the designing of the examination, establishing the period of testing and reporting of test scores. After implementation, further research should be done to assess the effectiveness of the examination and to look at ways of improving the certification process. Overtime, subject area certification may be applied to other subject areas and become a national requirement. 


\section{REFERENCES}

1. Baron, B. (1988). Assessment for national teacher certification. ERIC Digest 7-88. ED316545

2. Bradly, L. J. (1995). Certification and licensure issues. Journal of Counseling and Development 74 no $2185-186$

3. Brown, B. L. (1999). Vocational certificates and college degrees. ERIC Clearinghouse on Adult Career and Vocational Education, Columbus, OH. ERIC Digest.

4. Childs, R. A., Ross, M., and Jaciw, A. P. (2002). Initial teacher certification testing: preservice teachers' experiences and perceptions. Canadian Journal of Education 27 no 4 455-475

5. Darling-Hammond, L. (1999). Solving the dilemmas of teacher supply, demand and standards: how we can ensure a competent, caring, and qualified teacher for every child. New York, NY: Columbia University, Teachers College, the National Commission on Teaching and America's Future [Online] available: http://www.tc.columbia.edu/ teachcomm/CONFERENCE-99/SOLVING/

6. $\quad$ David, T. (2000). Teacher mentoring - benefits all around. Kappa Delta Pi Record 36 no3 134-6.

7. ERIC Digest 1. (1986). Alternative certification for teachers. ERIC Clearinghouse on Teacher Education, Washington DC. ERIC Digest (ED266137)

8. ERIC Digest 11. (1986). Teacher certification. ERIC Clearinghouse on Teacher Education Washington DC. ERIC Digest (ED277685).

9. Feiman-Nemser, S. (1996). Teacher mentoring: a critical review. ERIC Clearinghouse on Teaching and Teacher Education. Washington DC. ERIC Document Reproduction Service No. ED 392749.

10. Gold, Y. (1996). Beginning teacher support: attrition, mentoring, and induction. In J. Sikula (Ed.), Handbook of research on teacher education, 548-594. New York: Macmillan.

11. Goldhaber, D. and Anthony, E. (2005). Can teacher quality be effectively assessed? National board certification as a signal of effective teaching. The Urban Institute. Washington DC

12. Hosler, M. M. (Ed.). (2000). The chronology of business education in the United States 1635 - 2000. Reston, VA; NBEA

13. Joint Board of Teacher Education. (2003). Revised business education program. University of the West Indies, Mona Kingston JA

14. Morris, H. (1996). Technical and Vocational Education in Jamaica: development and democratization. Caribbean Journal of Education 18 no 2, 264 - 275

15. Nakai, K. and Turley, S. (2003). Going the alternate route: perceptions from non-credentialed teachers. Education 123 no 4, 831

16. National Business Education Association (1995). National standards for business education: what America's students should know and be able to do in business. Reston, VA, NBEA

17. Poelzer, H., Zeng, L., and Simonsson, M. (2000). Hispanic preservice teachers: variables that predict success on teacher certification exams. National Association of Hispanic and Latino Studies 2000. Literature Monograph Series Proceedings, Houston, TX.

18. Porter, A.C., Young, P., and Odden, A. (2001). Advances in teacher assessment and their uses. Handbook of Research on Teaching ( ${ }^{\text {th }}$ Ed.). American Educational Research Association, Washington DC.

19. Raymond, M.A., McNabb, D. E., and Matthaei, C.F. (1993). Preparing graduates for the workforce: the role of business education. Journal of Education for Business 68 no 4, 202 - 206

20. Robins, J. (2003). July 2003 results, Michigan test for teacher certification. Report to Eastern Michigan University, College of Education. National Evaluation System

21. Roth, R. R. and Mastain, R. (Eds.). (1984). The NASDTEC manual. National Association of State Directors of Teacher Education and Certification.

22. Task Force on Educational Reform Jamaica (2004). A transformed education system 2004 Report. Revised Edition. Presented to the Most Honorable P.J. Patterson by Chairman, Dr. Rae Davis, Kingston, JA.

23. Shulman, L. S. and Sykes, G. (1986). A national board for teaching? In search of a bold standard. A paper commissioned for the Task Force on Teaching as a Profession, Carnegie Forum on Education and the Economy

24. Stitt-Gohdes, W. (2002). The business education profession: principles and practices. Delta Pi Epsilon Society, Little Rock, AR.

25. Suh, T-F. R. (2002). The national council on teacher quality: expanding the teacher quality discussion. ERIC Clearinghouse on Teaching and Teacher Education Washington DC. ERIC Digest ED477730

26. UNESCO International Project on Technical and Vocational Education, UNEVOC (1997). Training of teachers/trainers in technical and vocational education. United Nations Educational, Scientific and Cultural Organization. France

27. Weaver, W. T. (1971). The Delphi forecasting method. Phi Delta Kappan 52 (5), 267-271 